Lucija Vejmelka*

Goran Brkic***

Katarina Radat***
Izvorni znanstveni rad

UDK 343.542-053.2

004.7:343.542-053.2

DOI: https://doi.org/10.25234/pv/4780

Rad primljen: 6. prosinca 2016.

\title{
DJEČJA PORNOGRAFIJA NA INTERNETU - OBILJEŽJA OSUĐENIH POČINITELJA
}

Sažetak:

\begin{abstract}
Štetne aktivnosti koje nastaju upotrebom modernih tehnologija uključuju i one štetne kontakte gdje je dijete ciljano izabrano kao žrtva od odrasle osobe. U radu će biti riječi upravo o skupini štetnih kontakata koja se odnosi na sudjelovanje u aktivnostima vezanim uz dječju pornografiju na internetu uz pomoć prikaza preliminarnih rezultata istraživanja.

Istraživanjem je analizirana dokumentacija probacijske službe 76 predmeta osuđenih počinitelja kaznenog djela iskorištavanja djece za pornografiju na internetu. Prikaz rezultata uključuje informacije o počiniteljima i vrsti kaznenog djela te ostale podatke koji će doprinijeti boljem razumijevanju kaznenih djela na štetu djece i maloljetnih osoba u području dječje pornografije i elektroničkog nasilja čime će se čime će se pridonijeti oskudnom istraživačkom području.
\end{abstract}

Ključne riječi: $\quad$ dječja pornografija na internetu, analiza dokumentacije, osuđeni odrasli počinitelji

\section{UVOD}

\subsection{KORISTI I RIZICI MODERNIH TEHNOLOGIJA}

Današnji život je nezamisliv bez uporabe modernih tehnologija, na prvom mjestu interneta, ali i ostale elektroničke komunikacije. Razvoj novih tehnologija donosi brojne koristi, moderne tehnologije omogućile su brže, jednostavnije i lakše komuniciranje s ljudima iz različitih dijelova svijeta te prenošenje različitih informacija. Internet je javna kompjutorska mreža koja

\footnotetext{
* Dr. sc. Lucija Vejmelka, docentica na Studijskom centru socijalnog rada Pravnog fakulteta Sveučilišta u Zagrebu. Nazorova 51 10000 Zagreb, Republika Hrvatska. Adresa e-pošte: lucija.vejmelka@pravo.hr. ORCID: https://orcid.org/0000-0002-7531-8457.

** Goran Brkić, dipl. soc. radnik, Ministarstvo pravosuđa. Ul. Grada Vukovara 49, 10000 Zagreb, Republika Hrvatska. Adresa e-pošte: goran.brkic@pravosudje.hr. ORCID: https://orcid.org/0000-0003-4753-8468.

*** Katarina Radat, dipl. soc. radnica, Društvo za socijalnu podršku, Bijenička 97, 10000 Zagreb, Republika Hrvatska. Adresa e-pošte: radat.katarina@gmail.com. ORCID: https://orcid.org/0000-0003-0580-9792.
} 
povezuje milijune korisnika diljem svijeta te upravo zbog svog globalnog karaktera ima brojne pozitivne strane, no već u prvim desetljećima njegova korištenja prepoznati su i mnogobrojni rizici, posebice za djecu i mlade, a izrazito zabrinjava fenomen postavljanja i dijeljenja dječje pornografije na internetu.

Prema podacima Državnog zavoda za statistiku rast korisnika interneta u Hrvatskoj primijećen je u svim dobnim skupinama (Državni zavod za statistiku, 2016.). ${ }^{1}$ Nadalje, istraživanje Hrabrog telefona i Poliklinike za zaštitu djece i mladeži ${ }^{2}$ pokazuje da više od $90 \%$ djece i mladih svakodnevno upotrebljava internet, najčešće preko svojih mobilnih telefona i u kućama, školama i sl.

Iako je internet izniman medij prema tehničkim mogućnostima, istodobno je otvorio brojna etička pitanja i dvojbe. Mnogi stručnjaci društvenih i zdravstvenih djelatnosti prisiljeni su preventivno i tretmanski djelovati sanirajući izuzetno teške i specifične posljedice koje su uzrokovane nekontroliranim korištenjem novog medija, a moguća je i pojava ovisničkih ponašanja o modernim tehnologijama. Posljedice su višestruke: od osobnih promjena koje uključuju pojave fizičkih i psihičkih poremećaja pojedinca do razvijanja različitih devijantnih ponašanja koja zadiru u područje kaznenog zakonodavstva na štetu, najčešće, maloljetnih osoba.

Dječja pornografija na internetu spada u kategoriju štetnih kontakta gdje je dijete ciljano izabrano kao žrtva od odrasle osobe radi iskorištavanja djece za pornografiju, slanja zlonamjernih sadržaja, zloupotrebe lozinki i ostalih osobnih podataka, upoznavanja osobe koju su upoznali u virtualnom okruženju. ${ }^{3}$

U ovom radu bit će riječ upravo o ovoj skupini štetnih kontakta koji se odnose na iskorištavanje djece od odraslih osoba radi dječje pornografije te sudjelovanje u aktivnostima vezanim uz dječju pornografiju na internetu. Cilj je ovog rada prikazati sociodemografska obilježja punoljetnih počinitelja kaznenih djela dječje pornografije na internetu te obilježja kaznenog djela i kaznenopravnih sankcija. Važno je naglasiti da je iskorištavanje djece za dječju pornografiju na internetu jedan od najekstremnijih oblika elektroničkog nasilja odraslih počinitelja prema djeci.

\subsection{DOSTUPNI STATISTIČKI PODACI}

Dostupni statistički podaci u području dječje pornografije ukazuju da je u Hrvatskoj ova pojava prisutna, a Kos i Rogić ${ }^{4}$ navode da su u šestogodišnjem razdoblju (od 2001. do 2006.) državna odvjetništva donijela 14 odluka o optuženju, dok su četiri kaznene prijave odbačene. Broj optuženih i osuđenih osoba prema istom članku Kaznenog zakona, u istom razdoblju, navodi da

1 Državni zavod za statistiku. Primjena informacijskih i komunikacijskih tehnologija (IKT) u kućanstvima i kod pojedinaca u 2016., Prvi rezultati. Priopćenje, LIII (2.3.2.), 2016. URL= http://www.dzs.hr/, pristupljeno 5. veljače 2017.

2 Hrabri telefon, Poliklinika za zaštitu djece grada Zagreba, Istraživanje o iskustvima i ponašanju djece na internetu i društvenoj mreži Facebook, 2013. URL=http://www.poliklinika-djeca.hr/aktualno/rijec-ravnateljice/ nase-istrazivanje-koliko-vremena-i-uz-kojerizike-djeca-provode-na-internetu-i-facebooku, pristupljeno 2. studenog 2015.

3 Vejmelka, L., Majdak, M., Specifičnosti nasilja kod djece smještene u domovima. Majdak, M.; Vejmelka, L.; Radat, K.; Vuga, A., (ur.), Zbornik konferencije Nasilje na Internetu među i nad djecom i mladima, Zagreb, 2014., str. 51.-74.

4 Kos, J., Rogić-Hadžalić, D., Kaznena djela na štetu djece i maloljetnika 2001 - 2006. Studije i analize 106, 2009. URL=http://www. dzs.hr/Hrv/publication/studije/Studije-i-analize-106.pdf, pristupljeno 14. siječnja 2016. 
je postupak završen za jedan slučaj te je počinitelj osuđen na uvjetnu kaznu zatvora od šest do dvanaest mjeseci. Iz statističkih podataka Državnog zavoda za statistiku u razdoblju od 2009. godine do 2014. godine imamo gotovo stopostotni porast izrečenih presuda vezanih uz članke Kaznenog zakona a koji se odnose na iskorištavanje djece za pornografiju i upoznavanje djece s pornografijom. Nadalje, usvajanjem novog Zakona broj presuda se udvostručio. Promatramo li razdoblje od 2009. do 2015. godine, vidimo da je prisutna tendencija rasta broja presuda od 5\%. ${ }^{5}$

Tablica 1. Broj kaznenih djela prema godinama

\begin{tabular}{|l|c|c|c|c|c|c|c|c|}
\hline \multirow{2}{*}{ Kazneno djelo } & \multicolumn{7}{|c|}{ Godina izricanja } \\
\cline { 2 - 9 } & $\mathbf{2 0 0 9 .}$ & $\mathbf{2 0 1 0 .}$ & $\mathbf{2 0 1 1 .}$ & $\mathbf{2 0 1 2 .}$ & $\mathbf{2 0 1 3 .}$ & $\mathbf{2 0 1 4 .}$ & $\mathbf{2 0 1 5 .}$ & Ukupno \\
\hline $\begin{array}{l}\text { Iskorištavanje djece ili maloljetnih osoba za } \\
\text { pornografiju čl. 196. (Narodne novine, broj } \\
\text { 110/1997) }\end{array}$ & 4 & 5 & 8 & 4 & 0 & $\mathbf{0}$ & $\mathbf{0}$ & $\mathbf{2 1}$ \\
\hline $\begin{array}{l}\text { Upoznavanje djece s pornografijom čl. 197. } \\
\text { (Narodne novine, broj 110/1997) }\end{array}$ & 5 & 8 & 5 & 5 & 0 & $\mathbf{0}$ & $\mathbf{0}$ & $\mathbf{2 3}$ \\
\hline $\begin{array}{l}\text { Dječja pornografija u računalnom sustavu ili } \\
\text { mreži 197.a (Narodne novine, broj 105/2004) }\end{array}$ & 11 & 21 & 16 & 23 & 0 & $\mathbf{0}$ & $\mathbf{0}$ & $\mathbf{7 1}$ \\
\hline $\begin{array}{l}\text { Iskorištavanje djece za pornografiju čl. 163. } \\
\text { (Narodne novine, broj 125/2011) }\end{array}$ & 0 & 0 & 0 & 0 & 18 & $\mathbf{2 4}$ & $\mathbf{2 5}$ & $\mathbf{6 7}$ \\
\hline $\begin{array}{l}\text { Upoznavanje djece s pornografijom čl. 165. } \\
\text { (Narodne novine, broj 125/2011) }\end{array}$ & 0 & 0 & 0 & 0 & 10 & $\mathbf{5}$ & $\mathbf{6}$ & $\mathbf{2 1}$ \\
\hline Ukupno & 20 & 34 & 29 & 32 & 28 & $\mathbf{2 9}$ & $\mathbf{3 1}$ & $\mathbf{2 0 3}$ \\
\hline
\end{tabular}

Izvor: Državni zavod za statistiku 2015.

Također je vidljiva tendencija rasta izrečene sankcije bezuvjetne osude nad uvjetnom osudom kada je riječ o navedenim kaznenim djelima iskorištavanja djece za pornografiju i upoznavanja djece s pornografijom. ${ }^{6}$

Tablica 2. Vrste sankcija

\begin{tabular}{|l|c|c|c|}
\hline \multirow{2}{*}{ Godina izricanja } & \multicolumn{3}{|c|}{ Vrsta sankcije } \\
\cline { 2 - 4 } & Uvjetno & Bezuvjetno & Ukupno \\
\hline 2009. & 9 & 11 & 20 \\
\hline 2010. & 11 & 23 & 34 \\
\hline 2011. & 8 & 21 & 29 \\
\hline 2012. & 14 & 18 & 32 \\
\hline 2013. & 11 & 17 & 28 \\
\hline 2014. & 7 & 22 & 29 \\
\hline 2015. & 14 & 17 & 31 \\
\hline Ukupno & 74 & 129 & 203 \\
\hline
\end{tabular}

Izvor: Državni zavod za statistiku 2015.

5 Državni zavod za statistiku, Punoljetni počinitelji kaznenih djela, prijave, optužbe i osude u 2014. Statistička izvješća: Zagreb, 2015. URL=http://www.dzs.hr/, pristupljeno 28. prosinca 2015. 
Derenčinović ${ }^{7}$ navodi kako je nemoguće ustanoviti točan broj izvora dječje pornografije na internetu, ali kako on zasigurno raste. Danas osuđenih počinitelja ima sve više, a raširenost interneta, informatička pismenost i virtualni kontekst u vidu anonimnosti korisnika te dostupnost različitih materijala i tehnika pružaju više prilika za kreiranje i distribuiranje nezakonitih pornografskih sadržaja.

Važno je naglasiti da stručnjaci navode kako je ovo područje još prilično neistraženo čime je otežana prevencija ali i tretman počinitelja. U ovom području nedostaju sustavna praćenja, evaluacije, istraživanja te analize koje bi pomogle da se multidisciplinarnim pristupom pridonese borbi suzbijanja dječje pornografije.

\subsection{DJEČJA PORNOGRAFIJA}

Dječju pornografiju najšire određujemo kao zloupotrebu djece u pornografske svrhe (Stanley, ${ }^{8}$ Wolak i sur.). ${ }^{9}$ Većina stručnjaka slaže se da dječja pornografija uključuje seksualizirane prikaze koji uključuju djecu, no nejasno je što sve obuhvaća pojam "seksualizirani". Pravne definicije naglašavaju općeni ili seksualni sadržaj prikaza kroz opise kaznenih djela, no detalji se razlikuju ovisno o legislativi različitih zemalja. Definiranje dječje pornografije na internetu predstavlja dodatan izazov budući da je virtualni prostor odraz globalnog društva u kojem sudjeluju pojedinci različitih kultura, moralnih vrijednosti i dolaze iz zemalja s različitim pravnim regulativama. ${ }^{10}$

Prema Konvenciji o pravima djeteta ${ }^{11}$ dijete je svaka osoba do 18 godina starosti. Konvencija o kibernetičkom kriminalu ${ }^{12}$ koristi izraz "maloljetnik" koji se također odnosi na sve osobe u dobi mlađoj od 18 godina te je istom predviđeno da država stranka može utvrditi i nižu dobnu granicu, ona ne može biti ispod 16 godina starosti.

Konvencija o kibernetičkom kriminalu u članku 9. definira dječju pornografiju kao pornografski materijal koji vizualno prikazuje maloljetnika koji sudjeluje u seksualno eksplicitnom ponašanju, osobu koja izgleda kao maloljetnik koji sudjeluje u seksualno eksplicitnom ponašanju ili stvarne slike navedenih radnji. ${ }^{13}$

7 Derenčinović, D., Dječja pornografija na Internetu - o kažnjivosti posjedovanja i virtualnoj dječjoj pornografiji, Hrvatski ljetopis za kazneno pravo i praksu, god. 10, br. 1, 2003., str. 3.-25.

8 Stanley, J., Child abuse and the Internet, National Child Protection Clearinghouse, no. 15, 2001, pp. 1-19.

9 Wolak, J.; Finkelhor, D.; Mitchell, K. J., Child-Pornography Possessors Arrested in Internet-Related Crimes: Findings From the National Juvenile Online Victimization Study. California, Florida, New York, Texas: National Center for Missing and Exploited Children, 2005, pp. 9-10.

10 Taylor, M.; Quayle, E.; Holland, G., Child Pornography: The Internet and Offending Isuma - Canadian, Journal of Policy Research, vol. 2, no. 2, 2001, pp. 94-100.

11 Unicef, Konvencija o pravima djeteta, 1991. URL=http://unicef.hr, pristupljeno 17. listopada 2015.

12 VijećeEurope,Konvencijaokibernetičkomkriminalu,2001.URL=http://narodne-novine.nn.hr/clanci/medunarodni/2002-07-9-119. html, pristupljeno 17. listopada 2015. 
Nešto specifičnija je definicija Konvencije o zaštiti djece od seksualnog iskorištavanja i seksualnog nasilja ${ }^{14}$ koja pojam "dječja pornografija” određuje kao bilo koji materijal koji vizualno prikazuje dijete koje sudjeluje u stvarnoj ili simuliranoj seksualno eksplicitnoj aktivnosti ili bilo koji prikaz spolnih organa djeteta u primarno seksualne svrhe (čl. 20. st. 2.).

Europski parlament i Vijeće EU-a usvojili su 2011. Direktivu ${ }^{15}$ o borbi protiv seksualnog nasilja i eksploatacije djece i dječje pornografije koja u članku 3. navodi da se dječja pornografija sastoji od slika seksualnog zlostavljanja djeteta i drugih posebno teških oblika seksualnog zlostavljanja i seksualnog iskorištavanja djece te da je rizik počinjenja i mogućnost dijeljenja ovakve vrste nezakonitih informacija olakšan korištenjem novih tehnologija i interneta.

Naš Kazneni zakon u skladu je s međunarodnim dokumentima, u članku 163. st. 6. navodi da je dječja pornografija materijal koji vizualno ili na drugi način prikazuje pravo dijete ili realno prikazano nepostojeće dijete ili osobu koja izgleda kao dijete, u pravom ili simuliranom spolno eksplicitnom ponašanju ili koji prikazuje spolne organe djece u spolne svrhe. ${ }^{16}$ Materijali koji imaju umjetnički, medicinski ili znanstveni značaj ne smatraju se pornografijom u smislu ovoga članka.

Iako definiciju dječje pornografije nalazimo u međunarodnim Konvencijama kao i u nacionalnim zakonodavnim odredbama, stručnjaci kritiziraju ovakvo pojmovno određenje kao neprimjereno te naglašavaju da se negira zlostavljačka priroda pornografskih materijala i trajnost posljedica ovog kaznenog djela za same žrtve. ${ }^{17}$ Derenčinović naglašava da kada je riječ o dječjoj pornografiji, bila ona stvarna ili virtualna, osnova zabrane nije samo u tome što bi ona mogla izazvati društvenu štetu, nego zbog toga što je ona univerzalno nemoralna i što ne podliježe moralnom relativizmu. ${ }^{18}$

Kod dječje pornografije potrebno je spomenuti i spolni grooming koji uključuje vrbovanje djece u spolne svrhe. Craven, Brown i Giachirst ${ }^{19}$ spolni grooming definiraju kao proces tijekom kojeg odrasla osoba priprema dijete ali i okolinu za spolnu zloupotrebu djeteta. Škrtić ${ }^{20}$ navodi kako su brojne aktivnosti groominga same po sebi legalne ali da u konačnici vode do nelegalnog spolnog kontakta s djetetom. Upravo se sustavnim i pomno promišljenim groomingom te manipulacijom dijete prinudi za sudjelovanje u pornografskim sadržajima.

Potrebno je naglasiti da je dječja pornografija kompleksan oblik seksualnog iskorištavanja djece koji je nerijetko povezan s drugim oblicima iskorištavanja djece, primjerice, trgovanjem

14 Vijeće Europe, Konvencija o zaštiti djece od seksualnog iskorištavanja i seksualnog nasilja, 2007. URL= http://www.coe.int/t/dghl/ standardsetting/children/Source/LanzaroteConvention-hr1.pdf, pristupljeno 17. listopada 2015.

15 Europski parlament, Vijeće Europe, Direktiva o borbi protiv seksualnog nasilja i eksploatacije djece i dječje Pornografije, br. 2011/92/ EU, 2011. URL= http://eur-lex.europa.eu/LexUriServ/LexUriServ .do?uri=OJ:L:2011: 335:0001:0014:EN:PDF, pristupljeno 12. ožujka 2016.

16 Kazneni zakon, Narodne novine, broj 125/2011, 144/2012, 56/2015 i 61/2015 - ispravak.

17 Assister, 1993., Beech i sur., 2008. prema Pavlović, Z.; Petković, N.; Matijašević Obradović, J., Dječja pornografija, Zbornik radova Pravnog fakulteta u Splitu, god. 51, br. 1, 2014., str. 45.-61.

18 Derenčinović, op. cit. u bilj 7, str. 19.

19 Craven, Brown i Giachirst prema Škrtić, D., Mamljenje djeteta za zadovoljenje spolnih potreba uporabom informacijsko-komunikacijske tehnologije, Zbornik Pravnog fakulteta Sveučilišta u Rijeci, god. 34, br. 2, 2013., str. 1139.-1170.

20 Škrtić, D., Mamljenje djeteta za zadovoljenje spolnih potreba uporabom informacijsko-komunikacijske tehnologije, Zbornik Pravnog fakulteta Sveučilišta u Rijeci, god. 34, br 2, 2013., str. 1139.-1170. 
djece i dječjom prostitucijom (Kahn, ${ }^{21}$ Klain i sur. ${ }^{22}$ ), no ova dimenzija fenomena iskorištavanja djece neće biti pobliže adresirana u ovom radu koji je usmjeren na obilježja počinitelja dječje pornografije u sustavu probacije.

\subsection{RELEVANTNI MEĐUNARODNI DOKUMENTI I NACIONALNO ZAKONODAVSTVO}

Nekoliko je relevantnih međunarodnih dokumenata koje je Republika Hrvatska ratificirala u području zaštite djece od izrabljivanja za pornografske sadržaje.

Konvencije o pravima djeteta ${ }^{23}$ (čl. 34.) obvezuje države stranke da zaštite dijete od svakog oblika spolnog izrabljivanja i zlostavljanja te da radi toga poduzmu sve nacionalne, bilateralne i multilateralne mjere kako bi spriječile: navođenje ili prinuđivanje djeteta na bavljenje bilo kojom nezakonitom spolnom djelatnošću; izrabljivačku uporabu djeteta u prostituciji ili kakvoj drugoj nezakonitoj spolnoj djelatnosti te izrabljivačku uporabu djeteta u pornografskim predstavama i materijalima. Fakultativni protokol uz Konvenciju o pravima djeteta o prodaji djece, dječjoj prostituciji i dječjoj pornografiji u Hrvatskoj potvrđen je 2002. godine. ${ }^{24}$

U trećem dijelu već spomenute Konvencije o kibernetičkom kriminalu (čl. 9.) detaljno se opisuju kaznena djela vezana uz dječju pornografiju. To su:

1. proizvodnja dječje pornografije radi njezine distribucije preko računalnih sustava

2. nuđenje ili činjenje dostupnim dječje pornografije preko računalnog sustava

3. distribuiranje ili prenošenje dječje pornografije računalnim sustavom

4. pribavljanje dječje pornografije preko računalnog sustava za sebe ili drugoga

5. posjedovanje dječje pornografije u računalnom sustavu ili na mediju za pohranu računalnih podataka. ${ }^{25}$

Republika Hrvatska supotpisnica je i Konvencije o zaštiti djece od seksualnog iskorištavanja i seksualnog nasilja koja predstavlja važan iskorak u sprječavanju seksualnog nasilja te zaštiti djece od iskorištavanja za pornografske sadržaje ali i ostale oblike seksualnog zlostavljanja gdje se navodi da će svaka stranka usvojiti zakonske ili druge mjere potrebne kako bi se kaznenopravno sankcionirao namjerni neovlašteni čin svjesnog ostvarivanja pristupa dječjoj pornografiji, preko informacijskih i komunikacijskih tehnologija čime se posebice definira dječja pornografija u virtualnom okruženju. ${ }^{26}$ Uporište ove Konvencije upravo su dvije navedene konvencije, no Konvencija o zaštiti djece od seksualnog iskorištavanja i seksualnog

21 Kahn, K., Child pornography on the Internet, Police Journal, 2000, pp. 7-17.

22 Klain, A. J.; Davies, H. J.; Hicks, M. A., Child Pornography: The Criminal-Justice-System Response, USA: American Bar Association Center on Children and National Center for Missing and Exploited Children, 2001, p. 1.

23 Ibid.

24 Zakon o potvrđivanju Fakultativnog protokola uz Konvenciju o pravima djeteta o prodaji djece, dječjoj prostituciji i dječjoj pornografiji, Narodne novine, Međunarodni ugovori, broj 5/2002.

25 Ibid.

26 Ibid. 
nasilja prvi je cjeloviti međunarodni instrument koji se prema seksualnom zlostavljanju djece postavlja kao prema zločinu, neovisno o tome tko ga je počinio i gdje je djelo počinjeno: u obitelji, u ustanovama, kroz mreže organiziranog kriminala ili preko interneta. Ova Konvencija je otvorena za ratifikaciju zemljama izvan Europe, kao i državama članicama Vijeća Europe te od zakonodavaca zahtijeva proširenje opsega statutarnog ograničenja prema kojem se slučajeve seksualnog zlostavljanja djeteta dovodi pred sud. ${ }^{27}$

Direktiva o borbi protiv seksualnog nasilja i eksploatacije djece i dječje pornografije utvrđuje minimalne kazne za dvadesetak kaznenih djela te obvezuje države članice na uvođenje predviđenih sankcija u vlastita zakonodavstva, ostavljajući državama članicama slobodu da same izaberu mjere za njihovo izvršenje i provedbu, uz uputu izricanja i novčane kazne uz kaznu zatvora u slučaju posebno teških oblika ove vrste kaznenih djela koja su počinjena s namjerom stjecanja ekonomske koristi. Važno je naglasiti da ova Direktiva ne sprječava primjenu dosadašnjih zakonskih okvira pojedine države članice na počinitelje navedenih prijestupa. ${ }^{28}$

U većini zakonodavstava posjedovanje pornografskog materijala koji sadrži seksualne zloporabe djece je kazneno djelo. U aktualnom Kaznenom zakonu (čl. 163.) odnosi se na iskorištavanje djece za pornografiju dok je u članku 164. navedeno iskorištavanje djece za pornografske predstave koji obuhvaća i sudjelovanje u aktivnostima vezanim uz dječju pornografiju na računalnom sustavu ili mreži. ${ }^{29}$

Kazneno djelo dječje pornografije u kazneno zakonodavstvo prvi put ulazi 1997. godine kada se u Kaznenom zakonu definira na sljedeći način: “Tko snimi dijete ili maloljetnu osobu za izradbu slika, audiovizualnog materijala ili drugih predmeta pornografskog sadržaja, ili prodaje, ili raspačava, ili prikazuje takav materijal, ili dijete navede na sudjelovanje u pornografskoj predstavi, kaznit će se kaznom zatvora od jedne do pet godina. “" ${ }^{30}$ Izmjenom Zakona ${ }^{31}$ navedeno kazneno djelo se dopunjuje tako da i posjedovanje sadržaja dječje pornografije postaje kažnjivo. Godine 2003. novom izmjenom Kaznenog zakona ${ }^{32}$ strože kažnjavanje ovog djela i to kaznom zatvora od jedne do osam godina propisano je u slučajevima ako je raspačavanje pornografskog sadržaja počinjeno preko računalne mreže tako da je time omogućen pristup većem broju osoba. Prvotno propisana kazna zatvora za počinitelje kaznenog djela iz stavka 1. članka 196. bila je od jedne do pet godina, ista se, izmjenom Kaznenog zakona 2006. ${ }^{33}$ godine povećava, novopropisana kazna zatvora je od jedne do osam godina. Ova kazna propisana je i danas prema važećem Kaznenom zakonu, ${ }^{34}$ sukladno navedenim međunarodnim propisima, za onoga tko dijete namamljuje, vrbuje ili potiče na sudjelovanje u snimanju dječje pornografije ili tko organizira ili omogući njezino snimanje, tko neovlašteno snima, proizvodi, nudi, čini dostupnim, distribuira, širi, uvozi, izvozi, pribavlja za sebe ili drugoga, prodaje, daje, prikazuje ili posjeduje dječju pornografiju ili joj svjesno pristupa preko informacijsko komunikacijskih tehnologija.

\footnotetext{
27 Ibid.

28 Ibid.

29 Ibid.

30 Kazneni zakon, Narodne novine, broj 110/1997.

31 Kazneni zakon, Narodne novine, broj 129/2000.

32 Kazneni zakon, Narodne novine, broj 111/2003.

33 Kazneni zakon, Narodne novine, broj 71/2006. 
Viša kazna zatvora od tri do dvanaest godina propisana je za kazneno djelo koje uključuje da je dijete silom ili prijetnjom, obmanom, prijevarom, zlouporabom ovlasti ili teškog položaja ili odnosa ovisnosti, prisiljeno ili navedeno na snimanje dječje pornografije (čl. 163. st. 3).

\subsection{POČINITELJI KAZNENIH DJELA ISKORIŠTAVANJA DJECE ZA PORNOGRAFIJU}

Istraživanja upućuju na neke specifične odrednice počinitelja kaznenih djela iskorištavanja djece za pornografiju. Taylor, Quaylea i Holland, koristeći podatke projekta COPINE koji od 1997. godine sustavno provodi Sveučilište u Corku, ${ }^{35}$ navode kako počinitelji kaznenih djela vezanih uz dječju pornografiju na internetu pokazuju mnoge sličnosti s drugim seksualnim prijestupnicima, no oni također pokazuju neke specifičnosti koje je važno razmotriti u vidu odgovarajućih procjena i tretmanskih programa za počinitelje. ${ }^{36}$ Henshaw, Ogloff i Clough, u svom preglednom radu navode osnovna obilježja počinitelja kaznenih djela povezanih s dječjom pornografijom te naglašavaju da su počinitelji ovakvih djela bili visokofunkcionalni i prihvaćeni u svojim lokalnim zajednicama te da su u povijesti bili rjeđe osuđivani od ostalih prijestupnika. ${ }^{37}$ Isti autori naglašavaju potrebu provođenja novih istraživanja koja bi dala još bolji uvid u karakteristike počinitelja dječje pornografije. Učestale dijagnosticirane patologije kod počinitelja nisu pronađene ni u istraživanju Price, Lambie i Krynena provedenog na Novom Zelandu s 46 počinitelja dječje pornografije. Navedeni autori ukazuju kako su počinitelji ovakve vrste djela često dobro integrirani pojedinci koji u svojim zajednicama nisu prepoznati kao prijetnja, a često ih odlikuje i dobar odnos s djecom u njihovoj blizini. ${ }^{38}$

Seto i Eke u istraživanju u kojem su koristili policijsku dokumentaciju o 201 počinitelju dječje pornografije navode kako je dječja pornografija čvrsti dijagnostički indikator pedofili$\mathrm{je}^{39}$ dok u istraživanju koje je provedeno u razdoblju od 1995. do 2004. (N=685) Seto Cantor i Blanchard upozoravaju da počinitelji s prijašnjim kaznenim djelima znatno češće ponavljaju djela na štetu djece i u budućnosti. ${ }^{40}$

Potrebno je naglasiti da nedostaje sustavnih istraživanja na ovom području te da često nisu reprezentativna, a istraživači nerijetko koriste vrlo različite metodološke pristupe pa su rezultati takvih istraživanja teško usporedivi. S obzirom na manjak istraživanja u ovom području, posebice u nacionalnom kontekstu, svaki nalaz predstavlja vrijedan doprinos za širenje spoznaja s ciljem prevencije i suzbijanja dječje pornografije.

35 Taylor, M.; Quayle, E.; Holland, G., The COPINE project, 2001. URL=http://web.archive.org/web/2007112 9132438/http:// copine.ie/, pristupljeno 21. ožujka 2016.

36 Ibid.

37 Henshaw, M.; Ogloff1, J. R. P.; Clough, J. A., A Critical Review of the Literature on the Online Child Pornography Offender, Sex Abuse, 2015, pii: 1079063215603690, p.15.

38 Price, M.; Lambie, I.; Krynen, A. M., New Zealand adult internet child pornography offenders, Journal of Criminal Psychology, vol. 5, no. 4, 2015, pp. 262-278.

39 Seto, M. C., Eke, A. W., The Criminal Histories and Later Offending of Child Pornography Offenders. Sexual Abuse, A Journal of Research and Treatment, vol. 17, no. 2, 2005, pp. 201-210.

40 Seto, M. C.; Cantor, J. M.; Blanchard, R. Child pornography offenses are a valid diagnostic indicator of pedophilia, Journal of Abnormal Psychology, vol. 115, no. 3, 2006, pp. 610-615. 


\section{SVRHA I CILJ ISTRAŽIVANJA}

Svrha ovog preliminarnog istraživanja jest da se na temelju identificiranih sociodemografskih karakteristika počinitelja te karakteristika kaznenog djela i izrečenih sankcija pridonese boljem razumijevanju kaznenih djela na štetu djece i maloljetnih osoba u području dječje pornografije i elektroničkog nasilja odraslih prema djeci. S obzirom na to da je riječ o deskriptivnom nacrtu istraživanja koje služi opisivanju osobina populacije počinitelja dječje pornografije na internetu nije potrebno postavljati probleme i hipoteze istraživanja.

Istraživanje je provedeno s ciljem identificiranja sociodemografskih obilježja punoljetnih počinitelja kaznenih djela koja uključuju dječju pornografiju i elektroničko nasilje te nekih specifičnosti samog kaznenog djela i kaznenopravnih sankcija.

\section{METODOLOGIJA}

Dokumentacija ima važnu funkciju u procjeni i planiranju što omogućuje pravodobno i prikladno donošenje odluka i planiranje intervencija i tretmana te sustavnu evaluaciju i praćenje s ciljem prevencije i daljnje zaštite djece (Sidel, ${ }^{41}$ Luepker i Norton, ${ }^{42}$ Reamer $^{43}$ ). Dokumentaciju je moguće analizirati s obzirom na formu i na sadržaj. Ovim preliminarnim istraživanjem provela se formalna i sadržajna analiza dokumentacije osuđenih počinitelja kaznenog djela dječje pornografije svih probacijskih ureda na području Republike Hrvatske. Sadržajna analiza uključuje deskriptivne podatke iz dokumentacije predmeta dok će se formalnom analizom provjeriti prisutnost pojedinih podataka u dokumentaciji osuđenih počinitelja.

Istraživanje je obuhvatilo ukupno 76 osuđenih počinitelja kaznenog djela dječje pornografije (dječja pornografija na računalnom sustavu ili mreži, iskorištavanje djece ili maloljetnih osoba za pornografiju, iskorištavanje djece za pornografiju, upoznavanje djece s pornografijom) koja su evidentirana u Probacijskom informacijskom sustavu, Sektora za probaciju, Uprave za kazneno pravo i probaciju Ministarstva pravosuđa. Time su obuhvaćeni svi počinitelji navedenih kaznenih djela na području Republike Hrvatske koje je probacijska služba u razdoblju od 21. prosinca 2009. do 3. rujna 2015. godine zaprimila na nadležno postupanje.

\subsection{METODE I NAČIN PROVEDBE ISTRAŽIVANJA}

Istraživanje je provedeno u razdoblju od srpnja do rujna 2015. godine analizom dostupne dokumentacije: presuda, rješenja o uvjetnom otpustu, pojedinačnih programa postupanja

41 Sidel, N. L., Social Work Documentation: A Guide to Strengthening Your Case Recording, Washington, D. C.: NASW Press, 2011.

42 Luepker, E., Norton, L., Record keeping in psychotherapy and counseling: Protecting confidentiality and the professional relationship, New York: Brunner-Routledge, 2002, pp.1-3. 
probacijskih ureda, izvješća iz kazneno-prekršajne evidencije i socioanamnestičkih podataka zatvora ili kaznionice osuđenih počinitelja kaznenog djela dječje pornografije.

\subsection{ISTRAŽIVAČKA ETIKA}

Istraživanje je uvažilo etičke smjernice pri provođenju istraživanja, suglasnost za provođenje istraživanja dobiveno je od Ministarstva pravosuđa, a s obzirom na povjerljivost podataka iz analize su uklonjeni osobni podaci iz kojih bi bilo moguće identificirati identitet počinitelja analizirane dokumentacije. Pristup podacima imali su isključivo istraživači koji, poštujući načelo povjerljivosti podataka, nisu upotrebljavali osobne podatke počinitelja ni kod prikaza rezultata ni kod diseminacije nalaza istraživanja.

\subsection{INSTRUMENT}

Radi istraživanja konstruirana je provjerna lista za prikupljanje podataka koja je uključila dvije skupine podataka. Prvim dijelom prikupljeni su sociodemografski podaci o počiniteljima dok se u drugom dijelu provjerne liste nalaze indikatori koji se odnose na obilježja kaznenog djela dječje pornografije te na obilježja izrečenih sankcija.

\section{REZULTATI ISTRAŽIVANJA I RASPRAVA}

\subsection{SOCIODEMOGRAFSKE KARAKTERISTIKE POČINITELJA KAZNENIH DJELA DJEČJE PORNOGRAFIJE}

Kaznena djela dječje pornografije u analiziranim predmetima počinile su isključivo osobe muškog spola. Prosječna starost počinitelja ovih kaznenih djela je 41,3 godine.

Najveći broj osuđenika je u dobi od 26 do 30 i od 36 do 40 godina, 26 ili 34,2\%. Prilično veliki broj osuđenika u dobi je od 56 godina i više, 13 ili 17,1\%.

Pogledamo li bračni status osuđenika 60,5\% neoženjene su osobe, samci i razvedeni, a udio osoba koje žive u bračnoj ili izvanbračnoj zajednici je 38,1\%.

Osuđeni počinitelji kaznenih djela dječje pornografije iz ovog istraživanja u 43,4\% slučajeva imaju vlastitu djecu, dok 55,2\% nema vlastitu djecu. Od osuđenika koji imaju djecu većinom imaju jedno dijete $21 \%$ ili dvoje djece $15,7 \%$ dok troje ili više djece ima 6,5\% osuđenika.

Rezultati istraživanja ukazuju da su osobe sa srednjom stručnom spremom češće počinitelji kaznenog djela dječje pornografije (65,8\%). Visokoobrazovane osobe (osobe s višom, visokom stručnom spremom i magisterijem) također su zastupljene u kategoriji počinitelja kaznenih djela dječje pornografije (21,1\%). U ovoj kategoriji osuđenika znatno je manji postotak počini- 
telja s niskom stručnom spremom, manje od $10 \%$ počinitelja. Možemo zaključiti da počinitelji kaznenog djela dječje pornografije spadaju u kategoriju obrazovanih počinitelja što je logičan slijed, jer za počinjenje ovog kaznenog djela osuđenici moraju imati neko informatičko znanje kako bi isto mogli počiniti. No važno je komentirati da osuđeni počinitelji kaznenog djela dječje pornografije dolaze iz različitih društvenih slojeva te da je s obzirom na sociodemografske karakteristike teško zaključiti o profilu osuđenih počinitelja dječje pornografije s obzirom na to da su različitog obrazovanja, obiteljskog i radnog statusa.

Struktura osuđenika prema radnom statusu uistinu je raznolika: od studenata, osoba koje imaju vlastitu tvrtku, obrt pa do umirovljenika. Najveći broj osuđenika je zaposlen $(44,7 \%)$, dok je nezaposlenih $38,1 \%$. I drugi autori koji se bave ovim područjem, primjerice McCarthy, ${ }^{44}$ u svom istraživanju navodi kako su počinitelji dječje pornografije heterogena skupina s obzirom na različita sociodemografska obilježja što je potvrđeno i ovdje prikazanim istraživanjem.

\subsection{OBILJEŽJA KAZNENIH DJELA I KAZNENOPRAVNIH SANKCIJA}

Probacijska služba je od stupanja na snagu Zakona o probaciji ${ }^{45}$ (21. prosinca 2009.) do 3. rujna 2015. godine na nadležno postupanje zaprimila ukupno 13.945 predmeta od čega se 76 ili 0,5\% ukupno zaprimljenih predmeta odnosi na predmete kaznenih djela dječje pornografije.

Ako predmete analiziramo po godini zaprimanja tada možemo reći kako je najveći broj predmeta zaprimljen u prvih devet mjeseci 2015 . godine $26,3 \%$, potom 2013 . godine $22,4 \%$, a 2012. i 2014. godine po 14,5\% ukupno zaprimljenih predmeta vezanih uz dječju pornografiju.

44 McCarthy, J. A., Internet sexual activity: A comparison between contact and non-contact child pornography offenders, Journal of Sexual Aggression, vol. 16, no. 2, 2010, pp. 181-195. 
Graf 1. Predmeti prema godini zaprimanja

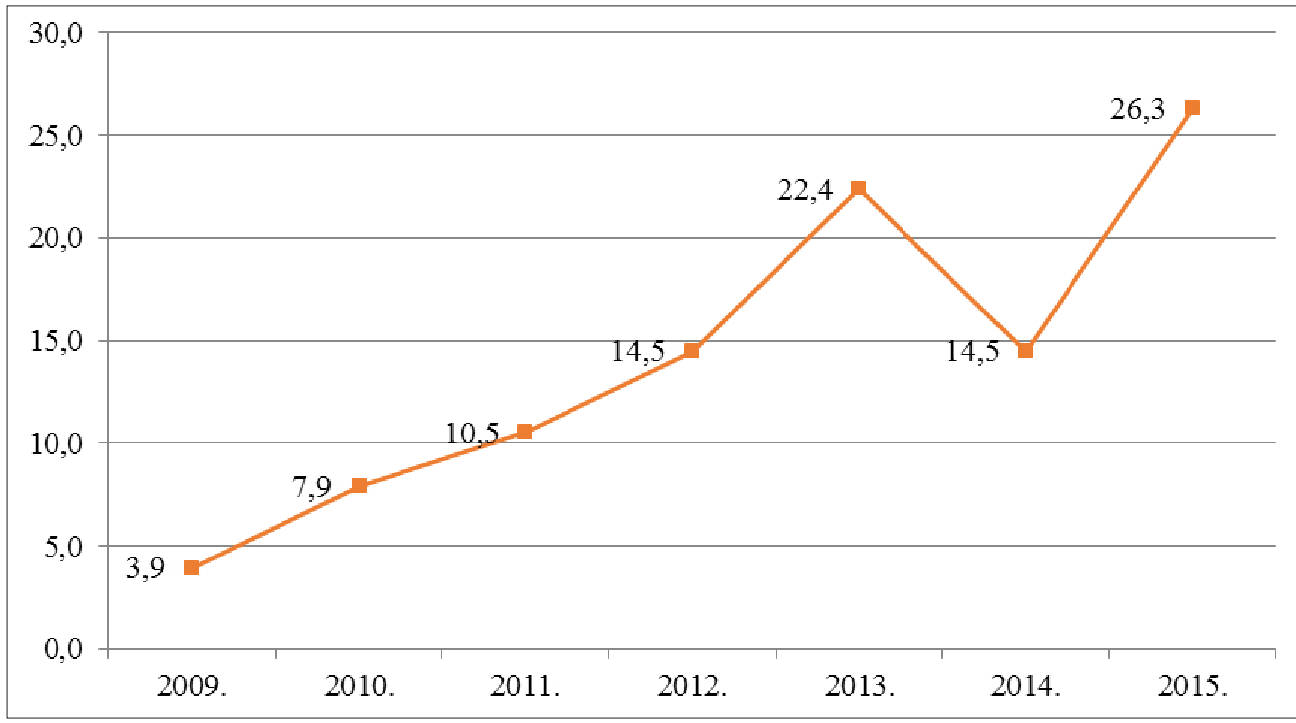

Iz Grafa 1. vidljivo je da je u razdoblju od 2013. do rujna 2015. zaprimljeno 63,2\% svih predmeta vezanih uz ovo kazneno djelo. Nadalje, 2013. godine u odnosu na 2012. zaprimljeno je $7,9 \%$ više predmeta, dok je u prvih devet mjeseci 2015. godine u odnosu na godinu prije zaprimljeno 11,8\% više predmeta. Mogući razlozi povećanja broja zaprimljenih predmeta vezanih uz ovo kazneno djelo vjerojatno uključuju povećanu aktivnost policije u otkrivanju ove vrste kaznenog djela, naime Ministarstvo unutarnjih poslova ulaže u edukaciju svojih stručnjaka u području cyber kriminalnih aktivnosti te u moderne tehnologije i sofisticirane računalne programe koji omogućavaju lakšu identifikaciju počinitelja. ${ }^{46}$ Stručnjaci posjeduju sve više znanja i vještina te su dostupni sofisticiraniji programski paketi za otkrivanje i praćenje istoga. Međunarodna umreženost i dobra educiranost stručnih službi omogućila je jednostavnije otkrivanje kaznenog djela u virtualnom svijetu. Relevantna je međunarodna umreženost Ministarstva unutarnjih poslova u Europol i Interpol međunarodne organizacije koje intenzivno rade na području smanjenja seksualnog iskorištavanja djece na internetu. ${ }^{47}$

Jedan od mogućih razloga povećanog broja počinitelja ogleda se u činjenici ubrzanog napretka tehnologije i sve veće informatičke pismenosti i dostupnosti interneta, a globalni karakter interneta i doživljaj anonimnosti online aktivnosti pružaju više prilika za počinjenje kaznenog djela.

Nadalje, pogledamo li prema godinama kada je izrečena presuda, vidimo da su iste izrečene u razdoblju od 2007. godine do 2015. godine, da se udio izrečenih presuda znatno povećava od 2012. godine. U razdoblju od 2012. do 2015. godine izrečeno je ukupno 68,5\% presuda dok je u od 2007. do 2011. godine izrečeno ukupno 31,5\% presuda. Također je vidljivo da su presude

46 MUP. Odjel za visokotehnološki kriminalitet. 2017. URL=http://www.policija.hr/159.aspx, pristupljeno 15. veljače 2017.

47 Europol, 2016. URL=https://www.europol.europa.eu/. Interpol, 2016. URL=https://www.interpol.int, pristupljeno 25. studenog 2016. 
izrečene mnogo prije nego što su zaprimljene od strane probacijskih ureda. Zaprimanje većeg broja predmeta od 2013. godine nadalje povezano je s činjenicom da probacijska služba početkom 2013. započinje s izvršavanjem nadzora uvjetnog otpusta te da dio osuđenika koji su osuđeni na bezuvjetnu zatvorsku kaznu ispunjava uvjete za uvjetni otpust te se isti otpuštaju na uvjetni otpust i dolaze pod nadzor probacijske službe.

Tablica 3. Kaznena djela dječje pornografije

\begin{tabular}{|l|c|}
\hline Naziv kaznenog djela & Broj djela \\
\hline Dječja pornografija na računalnom sustavu ili mreži čl. 197.a (Narodne novine, broj 105/2004) & 29 \\
\hline $\begin{array}{l}\text { Nedozvoljena uporaba autorskog djela ili izvedbe umjetnika izvođača čl. 230. (Narodne novine, broj 110/1997) } \\
\text { c čl. 197.a (Narodne novine, broj 105/2004) }\end{array}$ & 4 \\
\hline Iskorištavanje djece ili maloljetnih osoba za pornografiju čl. 196. (Narodne novine, broj 110/1997) & 7 \\
\hline Iskorištavanje djece za pornografiju čl. 163. (Narodne novine, broj 125/2011) & 31 \\
\hline Upoznavanje djece s pornografijom čl. 197. (Narodne novine, broj 110/1997) & 5 \\
\hline Ukupno & 76 \\
\hline
\end{tabular}

Kao što se može vidjeti 47,3\% predmeta odnosi se na počinitelje kaznenog djela Iskorištavanja djece ili maloljetnih osoba za pornografiju, dok je 38,1\%, počinjenja kaznenog djela Dječje pornografije u računalnom sustavu u mreži. Manji broj počinitelja kaznenog djela osuđen je zbog Upoznavanja djece s pornografijom (6,6\%), dok su preostali osuđenici (8\%) osuđeni za dva kaznena djela od kojih se jedno odnosi na kazneno djelo vezano uz dječju pornografiju (Tablica 3.). Najveći broj predmeta u kojima su počinitelji počinili dva ili više kaznenih djela odnosi se na kaznena djela Dječja pornografija na računalnom sustavu ili mreži i Nedozvoljena uporaba autorskog djela ili izvedba umjetnika izvođača. Naime, ovdje je riječ o slučaju kada su osuđenici koji su skidali dječju pornografiju s interneta na računalima posjedovali nelegalne softvere zbog čega su kažnjeni i za djelo nedopuštene uporabe autorskog djela ili izvedba umjetnika izvođača u stjecaju.

Tablica 4. Način počinjenja djela

\begin{tabular}{|l|c|}
\hline Način počinjena djela & $\begin{array}{c}\text { Broj } \\
\text { osuđenika }\end{array}$ \\
\hline S interneta skidao i na računalo spremao dječju pornografiju. & 54 \\
\hline Nisu dostupni podaci o počinjenju kaznenog djela. & 6 \\
\hline Presnimavao i distribuirao dječju pornografiju. & 5 \\
\hline $\begin{array}{l}\text { Na društvenoj mreži Facebooku dopisivao se s djetetom i tražio da mu šalje svoje nage slike lažno se } \\
\text { predstavljajući. }\end{array}$ & 4 \\
\hline Slikao maloljetnicu i njezine slike pohranjivao na svom mobitelu. & 1 \\
\hline Snimao spolni odnos s maloljetnicom, snimao njezine intimne dijelove i dalje ih distribuirao na internetu. & 2 \\
\hline Fotografirao maloljetnice i za to im plaćao a potom fotografije spremao na računalo. & 2 \\
\hline Naručivao i kupovao DVD-e s dječjom pornografijom. & 1 \\
\hline Slikao maloljetnu osobu i drugima distribuirao fotografije, koristio ih kao predložak za slikanje. & 1 \\
\hline Ukupno & 76 \\
\hline
\end{tabular}


Od ukupno analiziranih 76 presuda u njih šest nisu dostupni podaci o počinjenju kaznenog djela jer probacijskoj službi nije dostavljena presuda u kojoj je naveden način počinjenja kaznenog djela, nego samo rješenje o uvjetnom otpustu ili zahtjev za dostavu izvješća u kojem je navedeno kazneno djelo, ali ne i način na koji je isto počinjeno. Istraživanja koja uključuju način vođenja dokumentacije upućuju da su propusti u vođenju dokumentacije brojni i u drugim sustavima pa tako se u rezultatima istraživanja u sklopu međunarodnog BECAN ${ }^{48}$ projekta navodi kako centri za socijalnu skrb u slučajevima nasilja nad djecom sustavno ne bilježe niz relevantnih podataka poput podataka o počiniteljima, žrtvama ali i o samom događaju ili u ovom slučaju kaznenom djelu, a slična situacija zatečena je i kod dokumentacije počinitelja dječje pornografije na internetu.

Najčešći oblik počinjenja kaznenog djela odnosi se na skidanje sadržaja s interneta (s interneta skidao i na računalo spremao dječju pornografiju) u presudama je opis naveden tako da je opisano razdoblje u kojem je djelo počinjeno kao i način počinjenja djela (primjerice, jesu li posjećivane internetske stranice sa sadržajima dječje pornografije, jesu li fotografije i videoisječci na kojima su djeca prikazana u spolno eksplicitnom ponašanju i koje prikazuju spolne organe djece u spolne svrhe spremljene na računalo).

Četvorica osuđenika kazneno djelo počinila su lažno se predstavljajući na društvenim mrežama, što je u presudama opisano na način da je navedeno preko koje društvene mreže kao i naziv lažnih profila te opisan kontakt s djetetom, učestalost kao i način na koji je dijete nagovoreno da primjerice snimi fotografije svog spolovila, grudi i cijelog nagog tijela koje su poslane osuđenom počinitelju, naveden je broj takvih fotografija te činjenica da su pohranjenje na računalu ili pametnom telefonu počinitelja. S obzirom na istraživačku etiku i zajamčenu povjerljivost podataka u ovom radu nisu prikazani ili citirani dijelovi presuda.

Za sva navedena kaznena djela osuđenicima je izrečena uvjetna zatvorska kazna koja je zamijenjena radom za opće dobro čime im je dana prilika da za počinjeno kazneno djelo ne idu u zatvor nego da na slobodi odrade izrečeni broj sati rada za opće dobro. Osuđenici su dobili sljedeće kaznenopravne sankcije: bezuvjetnu zatvorsku kaznu, uvjetnu zatvorsku kaznu koja je zamijenjena radom za opće dobro i uvjetnu zatvorsku kaznu sa zaštitnim nadzorom.

Najveći broj osuđenika, za počinjenje kaznenih djela povezanih s dječjom pornografijom, osuđen je na uvjetnu zatvorsku kaznu koja je potom zamijenjena za rad za opće dobro 59 osuđenika ili 77,6\%, uvjetnu osudu sa zaštitnim nadzorom jedan osuđenik, dok su ostalih 26 ili $34,2 \%$ osuđenika, osuđeni na bezuvjetnu zatvorsku kaznu.

Zabrinjava podatak da je u najvećem broju predmeta koje je probacija zaprimila na nadležno postupanje osuđenicima izrečena kazna zatvora u trajanju od šest mjeseci i to 40 predmeta ili 52,6\%, potom na kaznu zatvora u trajanju od 12 mjeseci 25 predmeta ili 32,9\%, te u trajanju od osam mjeseci tri predmeta ili 3,9\%. Prema svemu navedenom možemo zaključiti da su suci počiniteljima ovih kaznenih djela u $89 \%$ predmeta izrekli kaznu zatvora do godine dana, što ukazuje na potrebu daljnjih istraživanja s ciljem razumijevanja donošenja odluke sudaca o trajanju zatvorske kazne za ovu vrstu počinjenog kaznenog djela. Ako ovome pridodamo da je u 77,6\% predmeta izrečena kazna zatvora zamijenjena radom za opće dobro koji nije tretmanska sankcija, dok je samo jednom osuđeniku izrečena uvjetna osuda sa zaštitnim nadzorom,

48 Ogresta, J.; Rimac, I.; Ajduković, M.; Skokandić, L., Analiza obilježja prijavljenih događaja nasilja nad djecom u obitelji evidentiranih u centrima za socijalnu skrb, Ljetopis socijalnog rada, god. 19, br. 3, 2012., str. 439.-477. 
proizlazi da je samo jednoj trećini osuđenika, koji su zbog počinjenja kaznenog djela dječje pornografije dospjeli pod nadzor probacijske službe, izrečena zatvorska kazna.

U dva predmeta navedeno je da je počinitelj počinio navedeno kazneno djelo, ali nije navedeno trajanje zatvorske kazne na koju je isti osuđen. Na najdužu kaznu u trajanju od deset godina osuđen je samo jedan počinitelj koji je počinio sljedeća kaznena djela: spolni odnošaj s djetetom, zadovoljenje pohote pred djetetom ili maloljetnom osobom, bludne radnje, iskorištavanje djece ili maloljetnih osoba za pornografiju, upoznavanje djece s pornografijom.

Podaci dobiveni ovim istraživanjem jasno upućuju na činjenicu da su suci pri odmjeravanju zatvorske kazne bili prilično blagi te su počiniteljima, u najvećem broju predmeta, izrekli minimalnu zatvorsku kaznu. Pretpostavlja se da je procjena bila da će se i izricanjem minimalne kazne postići svrha kažnjavanja sukladno članku 41.: "Svrha kažnjavanja je izraziti društvenu osudu zbog počinjenog kaznenog djela, jačati povjerenje građana u pravni poredak utemeljen na vladavini prava, utjecati na počinitelja i sve druge da ne čine kaznena djela kroz jačanje svijesti o pogibeljnosti činjenja kaznenih djela i o pravednosti kažnjavanja te omogućiti počinitelju ponovno uključivanje u društvo." ${ }^{49}$ Kada se počiniteljima ovih kaznenih djela izrekne minimalna zatvorska kazna koja se potom još zamijeni radom za opće dobro, postaje upitno koliko je ovakvom kaznom postignuta svrha kažnjavanja, osobito utjecaj iste na počinitelja kao i jačanje svijesti o pogibeljnosti činjenja kaznenih djela.

Najveći broj počinitelja (71\%) počinilo je kazneno djelo tako da je s interneta skidao i na osobno računalo ili neke druge medije spremao sadržaje dječje pornografije, dok je 6,5\% osuđenika presnimavalo i dalje distribuiralo sadržaje dječje pornografije (Tablica 4.). Važno je komentirati da počinitelji dječje pornografije na internetu mogu imati različite motive za počinjenje ovog kaznenog djela što bi svakako bilo važno uključiti u buduća istraživanja u ovom području. Najčešće ih dijelimo na seksualne prijestupnike kojima kontakt s djecom seksualne prirode (online ili offline) ili sadržajima dječje pornografije izaziva seksualno uzbuđenje te na one prijestupnike koji se organiziraju u zločinačke organizacije kako bi distribuirali sadržaje dječje pornografije na kojima zarađuju velike novčane iznose. ${ }^{50}$

Kažnjavanje ovog djela je zadovoljavajuće zakonski uređeno, propisana je relativno visoka zatvorska kazna i sucu je dana mogućnost da, s obzirom na sve okolnosti, osuđeniku odredi najprimjereniju sankciju. Osuđeniku je moguće izreći uvjetnu ili bezuvjetnu zatvorsku kaznu te mu je moguće naložiti izvršavanje cijelog spektra posebnih obveza propisanih kaznenim zakonom: od obveznog psihijatrijskog liječenja pa nadalje. Za počinjenje ovog kaznenog djela nije nužno izreći bezuvjetnu zatvorsku kaznu, ali ako je osuđeniku potreban intenzivniji tretman radi odvraćanja ponovnog počinjenja istog ili sličnog kaznenog djela, tada je moguće izreći uvjetnu osudu sa zaštitnim nadzorom s posebnom obvezom ili bez nje.

Uvjetna osuda sa zaštitnim nadzorom s posebnom obvezom ili bez nje sankcija je u kojoj se cijelo vrijeme provjeravanja intenzivno radi s osuđenikom. Na početku izvršavanja zaštitnog nadzora probacijski službenik će osuđenika upoznati s njegovim pravima i obvezama te o načinu i dinamici izvršavanja sankcije. Najkasnije u roku od 30 dana od dana javljanja osuđenika

49 Ibid.

50 Seto, M., Chapter 4: Internet-Facilitated Sexual Offending, 2015. URL= http://www.smart. gov/SOMAPI /sec1/ch 4-internet. html, pristupljeno 25. studenog 2016. 
izradit će se Pojedinačni program postupanja (dalje u tekstu Program) u kojem će, na temelju podataka iz presude, podataka o prethodnoj kažnjavanosti osuđenika te procjeni utvrđenih kriminogenih čimbenika, definirati postupke usmjerene na njihovo otklanjanje, aktivnosti koje treba poduzeti, rokove za njihovo provođenje i nositelje pojedinih aktivnosti. Radi izvršavanja Programa probacijski službenik je u redovitom kontaktu s osuđenikom, a najmanje svakih 14 dana, tijekom prvih dvanaest mjeseci trajanja zaštitnog nadzora, a zatim najmanje jedanput na mjesec do isteka roka za koji je zaštitni nadzor određen te će se o izvršenju redovito izvještavati nadležni sud. ${ }^{51}$

Ova sankcija se u Republici Hrvatskoj u najvećem postotku izricala počiniteljima obiteljskog nasilja za koje je sud procijenio da i bez izvršenja kazne zatvora neće ubuduće činiti kaznena djela. Uz zaštitni nadzor ovim počiniteljima je obično izricana i posebna obveza iz članka 62. stavka 2. točka 6. koja glasi: "Sudjelovanje ili nastavak sudjelovanja u postupku psihosocijalne terapije u zdravstvenim ustanovama ili u pravnim ili kod fizičkih osoba specijaliziranim za otklanjanje nasilničkog ponašanja." Sud je očito procijenio da je kod ovih počinitelja, osim kažnjivog ponašanja koje će sankcionirati izricanjem uvjetne kazne zatvora, potreban i tretman počinitelja kako ne bi više počinio isto ili slično kazneno djelo.

Ako se vodimo sličnom analogijom, tada bi i za djelo dječje pornografije trebalo izreći uvjetnu osudu sa zaštitnim nadzorom i sljedećom posebnom obvezom: liječenje ili nastavak liječenja koje je nužno radi otklanjanja zdravstvenih smetnji koje mogu poticajno djelovati za počinjenje novog kaznenog djela. Seto, Cantor i Blanchar (2006.) istraživanjem potvrđuju da je počinjenje kaznenog djela dječje pornografije snažan indikator za dijagnozu pedofilije koja se nalazi u Međunarodnoj klasifikaciji bolesti (MKB 10). Također isti autori upozoravaju da je počinjenje kaznenog djela dječje pornografije čak snažniji indikator nego počinjenje nekih drugih seksualnih kaznenih djela s djecom. ${ }^{52}$

\subsection{OSTALE KARAKTERISTIKE POČINJENJA KAZNENOG DJELA}

Izravni kontakt sa žrtvom imalo je jedanaest osuđenika dok su preostali osuđenici obuhvaćeni ovim istraživanjem kazneno djelo počinili u virtualnom okruženju bez izravnog kontakta s djetetom. Istraživanje Bourkea i Hernandez navodi da počinitelji kaznenih djela pornografije na internetu će znatno češće počiniti i kaznena djela iskorištavanja djece za pornografiju ukaže li im se prilika te da je jedan dio osuđenih počinitelja imao izravan kontakt s djetetom radi seksualnih iskorištavanja iako za to djelo nisu osuđeni i nije prikazan u njihovoj dokumentaciji s obzirom na to da su nakon uhićenja minorizirali učinjena kaznena djela te su priznali samo ona djela za koja postoje čvrsti dokazi. ${ }^{53}$ Dakle, nalazi spomenutog istraživanja upućuju da je rizik od izravnog kontakta radi iskorištavanja djece viši za one koji su prethodno osuđeni za kaznena djela dječje pornografije koja nisu uključivala izravan kontakt s djecom ili da taj kontakt nisu priznali u kaznenom postupku.

51 Pravilnik o načinu obavljanja probacijskih poslova, Narodne novine, broj 143/2012.

52 Seto; Cantor; Blanchard, op. cit. u bilj. 40, str. 611.

53 Bourke, M. L., Hernandez, A. E., The 'Butner Study' Redux: A Report of the Incidence of Hands-on Child Victimization by Child Pornography Offenders, Journal of Family Violence, no. 24, 2008, pp.183-191. 
Osuđenici koji su bili u kontaktu sa svojim žrtvama istima su otprije bili poznati, bilo da su im susjedi, prijatelji njihovih roditelja ili maloljetne djece, a jedan osuđenik je u srodstvu sa žrtvom (očuh žrtve). I ostali autori navode da su djeca najčešće seksualno zlostavljana i iskorištavana od poznatih osoba. Cawson i suradnici navode da su počinitelji osobe poznate djeci, no ne nužno i u krvnom srodstvu s djecom. ${ }^{54}$ Richards također naglašava da je većina počinitelja ovakvih djela poznavala svoje žrtve te da dokumentacija pokazuje kako je riječ o muškom članu rodbine, roditelju ili očuhu, obiteljskom prijatelju, znancu ili susjedu ili drugoj poznatoj osobi. ${ }^{55}$ Ovdje je potrebno ponovno spomenuti pojam spolnog groominga koji definira vrbovanje djece u spolne svrhe. Naime, informacije o tome na koji način je dijete namamljeno da sudjeluje u spolnim radnjama, nisu poznate. Spolni grooming uključuje pribavljanje pristupa djetetu primjerice uspostavom kontakta uz pomoć informacijsko-komunikacijskih tehnologija, zadobivanje povjerenja djeteta i uspostave emocionalne veze te odražavanje tajnosti radi sprječavanja otkrivanja kaznenog djela. ${ }^{56}$

Za osuđenike koji su bili na izvršavanju bezuvjetne zatvorske kazne rađena je, prije upućivanja na izdržavanje kazne u kaznionicu, u Centru za dijagnostiku, kompletna obrada u kojoj su prikupljeni svi socioanamnestički podaci. Pri uvjetnome otpustu probacijskoj službi su, za dio počinitelja, dostavljene anamneze iz kojih je vidljivo da je kod njih ukupno sedam u primarnoj obitelji zabilježen neki oblik socijalne patologije. Najčešće je bila riječ o alkoholizmu oca, nasilju u obitelji i narušenim partnerskim odnosima i rastavi roditelja. Osim patologije u obitelji kod istih je naveden i neki oblik socijalne patologije, najčešće alkoholizam samih počinitelja, potom depresivnost, pokušaj suicida i PTSP.

U ovom području također treba ukazati na mogućnosti unaprjeđenja vođenja dokumentacije pravosudnog sustava. Podaci o socijalnoj patologiji počinitelja sustavno se ne bilježe kao ni u sustavu socijalne skrbi kada govorimo o nasilju nad djecom. ${ }^{57}$ Dakle, ne postoji sustavno detaljno praćenje karakteristika počinitelja nasilja nad djecom, zlostavljača i onih koji ih iskorištavaju za seksualne aktivnosti, što upućuje na manjak dostupnih podataka te spoznaja o počiniteljima na kojima bi bilo moguće temeljiti učinkovite modele tretmana.

Da bi dokumentacija bila kvalitetna, važno je da su stručni radnici upoznati s različitim procedurama i propisima te da je jasno navedeno koji su podaci relevantni i potrebni da budu uključeni u dokumentaciju. Kagle i Koples navode da standardi i upute za vođenje dokumentacije trebaju eksplicitno odrediti tipove dokumentacije, njezinu svrhu i namjenu, načine na koje će se dokumentacija koristiti, okolnosti pod kojima je nužno bilježiti različite tipove informacija, formate i formulare koje treba koristiti, kao i vremenski okvir za pregled, reviziju i unošenje novih informacija u dokumentaciju. ${ }^{58}$ I ostali autori navode kako kvalitetni podaci i dobro praćenje slučajeva i vođenje dokumentacije predstavljaju “snažno oružje koje pridonosi planiranju i primjeni općih i specifičnih politika”. ${ }^{59}$ Ogresta i suradnici su se bavili kvalitetom

54 Cawson P.; Wattam C.; Brooker S.; Kelly G., Child maltreatment in the United Kingdom: A study of the prevalence of abuse and neglect. NSPCC, London, 2000, p. 16.

Škrtić, D. Mamljenje djeteta za zadovoljenje spolnih potreba uporabom informacijsko-komunikacijske tehnologije, Zbornik Pravnog fakulteta Sveučilišta u Rijeci, god. 34, br. 2, 2013., str. 1139.-1170. 
postojećeg sustava dokumentiranja prijavljenih događaja nasilja nad djecom u sustavu socijalne skrbi navode da je pravosudni sustav usmjeren na identificiranje kaznenih ili prekršajnih djela i sankcioniranje počinitelja te da podaci koji se prikupljaju u tom sustavu nude temeljne podatke o opsegu pojave u skladu sa zakonskim određenjima a primarno su usmjereni na počinitelje. Isti autori navode kako djelokrug djelovanja pravosudnog sustava nije pružanje neposrednih usluga zbrinjavanja žrtava iako bi svojim djelovanjem ovaj sustav trebao zaštititi dijete žrtvu od daljnjeg nasilja, sankcionirajući počinitelja ili/i obavezujući ga na određene zaštitne mjere uključujući psihosocijalni tretman. ${ }^{60}$

\section{ZAKLJUČNA RAZMATRANJA}

Nalazi ovog istraživanja pridonose boljem razumijevanju osuđenih počinitelja kaznenog djela dječje pornografije na internetu. Počinitelji dječje pornografije dolaze iz svih društvenih slojeva, iz različitih su obrazovnih skupina i podjednako ih je s obzirom na bračni status. Gotovo polovina osuđenika ima vlastitu djecu, a nešto manje od $15 \%$ od ukupnog broja sudionika istraživanja priznaje izravan kontakt sa žrtvom. S obzirom na nalaze sociodemografskih karakteristika sudionika istraživanja nije moguće zaključiti o profilu počinitelja dječje pornografije na internetu. Rezultati koji se odnose na obilježja kaznenopravnih sankcija zabrinjavaju s obzirom na to da gotovo polovina počinitelja u penalnoj ustanovi ostaje samo šest mjeseci, dok je oko 25\% sudionika u kaznionici provelo dvanaest mjeseci što su minimalne, zakonom izrečene sankcije. Na ovom području potrebna su dodatna istraživanja koja bi pridonijela razumijevanju kaznenog djela dječje pornografije na internetu radi prevencije te tretmana osuđenih počinitelja. Pomno planirana istraživanja trebala bi uključiti različite izvore podataka (analiza dokumentacije, osuđeni počinitelji, suci, stručnjaci koji rade s osuđenim počiniteljima) što bi omogućilo cjelovitiji uvid u područje rada s osuđenim počiniteljima i mogućnostima unaprjeđenja u ovom području.

Kako je istaknuto u raspravi, područje iskorištavanja djece za pornografiju na internetu zakonski je zadovoljavajuće definirano, propisan je relativno velik raspon kazne zatvora koja se može izreći osuđeniku (od jedne do osam godina), a koja može biti uvjetna ili bezuvjetna, te se ista može kombinirati s različitim mjerama i obvezama. Kazneni zakon je sudskoj praksi omogućio individualizaciju kazne i odabir najprimjerenije sankcije. Zbog čega su suci najvećem broju počinitelja ovih djela izrekli najnižu zatvorsku kaznu i istu zamijenili radom za opće dobro, svakako je pitanje na koje odgovor mogu dati samo oni koji su tu sankciju i izrekli. U sljedećim istraživanjima svakako bi trebalo istražiti mišljenje sudaca o ovom području. Jedna od mogućnosti bila bi preko programa Pravosudne akademije upoznati suce s rezultatima ovoga i ostalih istraživanja i sa zaključcima navedene rasprave te ih potaknuti da počiniteljima kaznenih djela dječje pornografije izriču prikladne tretmanske sankcije.

Na području rada s počiniteljima djela dječje pornografije potrebna je dodatna edukacija stručnjaka u području usvajanja znanja i vještina prikupljanja dokaza u vidu fotografija i ostalog kriminirajućeg materijala koji će ujedno postati forenzički dokaz u postupku. Osobito je 
važno da prate objave i elektroničku komunikaciju za što je nužno da su upoznati s virtualnim ponašanjima te jezikom kojim se služe počinitelji ovih kaznenih djela.

Kvalitetno vođenje dokumentacije o počiniteljima djela iskorištavanja djece za pornografiju korisno je na više razina, zbog produbljivanja znanja o počiniteljima i kaznenom djelu te zbog prikladnog planiranja tretmana i sankcija radi suzbijanja aktivnosti vezanih uz dječju pornografiju. Dostupnost kvalitetnih informacija omogućilo bi provođenje analiza i istraživanja te bi omogućile praksu temeljenu na dokazima i pomogli bi stručnjacima i praktičarima za djelotvorniji rad u penalnom i postpenalnom tretmanu osuđenih odraslih počinitelja. Potrebno je naglasiti kako u Hrvatskoj ne postoji sustavni tretmanski rad s počiniteljima kaznenog djela dječje pornografije, a rezultati ovog istraživanja potvrđuju potrebu daljnje senzibilizacije stručnjaka za potrebu uvođenja djelotvornog tretmana i u pravosudnom sustavu kao i u sustavu socijalne skrbi. Prikladne kaznenopravne sankcije za ova kaznena djela u kombinaciji s mogućnostima djelotvornog tretmanskog rada s počiniteljima omogućilo bi sustavnu međusektorsku suradnju na ovom području, a kvalitetno vođenje dokumentacije nužan je preduvjet za pomno planirane i prikladne intervencije. Kako je na ovom području prisutan nedostatak istraživanja, a dostupni statistički podaci su relativno skromni, vodeći se načelima prakse utemeljene na dokazima od izuzetne je važnosti provoditi daljnja istraživanja. Službena dokumentacija u pravosudnom sustavu važan je izvor informacija o počiniteljima kaznenog djela iskorištavanja djece za pornografiju. Kvalitetno vođenje dokumentacije omogućilo bi sustavno praćenje karakteristika počinitelja pa je potrebno promovirati načine kvalitetnog vođenja dokumentacije. Kagle i Koples navode da su potrebni detaljni standardi i uputa o svrsi, namjeni i načinima vođenja dokumentacije uz jasne vremenske okvire. ${ }^{61} \mathrm{~S}$ obzirom na nalaze ovog istraživanja posebnu pozornost trebalo bi posvetiti detaljnijoj dijagnozi obiteljske patologije i patologije počinitelja što bi bilo od koristi pri uvođenju tretmana za počinitelje. Također skromni su podaci o samom počinjenju kaznenog djela.

Nadalje, Clough ${ }^{62}$ navodi kako su nacionalni i internacionalni napori za suzbijanje dječje pornografije u porastu, no da je širokom upotrebom interneta porasla potreba za učinkovitim i žurnim sankcioniranjem ovih kaznenih djela. Iskorištavanje interneta za pornografiju jedan je od najvećih rizika modernih tehnologija za djecu i mlade, stoga je potrebno pokrenuti široku stručnu raspravu i jasno definirati ovo područje kako bi se pomoglo sucima pri odabiru najprimjerenije kaznenopravne sankcije za počinitelje ovog kaznenog djela kojom će se u konačnici postići sama svrha kažnjavanja, a to je da počinitelj više ne čini kaznena djela. Osim primjerenijih sankcija koje uključuju uz izricanje zatvorske kazne i mjeru psihosocijalnog tretmana radi osvještavanja težine kaznenog djela kod počinitelja, otklanjanja poremećaja ukoliko je dijagnosticiran i ujedno i sprječavanja daljnjeg ponavljanja kaznenog djela na štetu maloljetnika, potrebno je provoditi dodatna istraživanja čiji bi nalazi omogućili praksu temeljenu na dokazima (evidence-based).

Završno, sustavna borba suzbijanja dječje pornografije zahtijeva multidisciplinaran pristup i multisektorsku suradnju. Konvencija o zaštiti djece od seksualnog iskorištavanja i sek-

61 Kagle, Koples, op. cit. u bilj. 59.

62 Clough, J., Lawful acts, unlawful images: the problematic definition of child pornography, Monash University Law Review, god. 38, br. 3, 2012., str. 213.-245. 
sualnog nasilja u dijelu ${ }^{63}$ koji se odnosi na Nacionalne mjere koordinacije i suradnje upućuje da će svaka stranka poticati suradnju među nadležnim državnim tijelima, civilnim društvom i privatnim sektorom radi učinkovitijeg sprječavanja i suzbijanja seksualnog iskorištavanja i seksualnog zlostavljanja djece te razvijati mehanizme za prikupljanje podataka ili koordinacijska tijela na državnoj ili lokalnim razinama te u suradnji s civilnim društvom, a radi promatranja i ocjene pojave seksualnog iskorištavanja i seksualnog zlostavljanja djece, uz poštovanje zahtjeva vezanih uz zaštitu osobnih podataka.

\section{LITERATURA}

1. Assister, 1993., Beech i sur., 2008. prema Pavlović, Z.; Petković, N.; Matijašević Obradović, J., Dječja pornografija, Zbornik radova Pravnog fakulteta u Splitu, god. 51, br.1, 2014., str. 45.-61.

2. Bourke, M. L., Hernandez, A. E., The 'Butner Study' Redux: A Report of the Incidence of Hands-on Child Victimization by Child Pornography Offenders, Journal of Family Violence, br. 24, 2008, str. 183.-191.

3. Cawson, P.; Wattam, C.; Brooker, S.; Kelly G., Child maltreatment in the United Kingdom: A study of the prevalence of abuse and neglect. 2000, London: NSPCC. p. 16.

4. Clough, J., Lawful acts, unlawful images: the problematic definition of child pornography, Monash University Law Review, vol. 38, no. 3, 2012, pp. 213-245.

5. Craven, Brown i Giachirst prema Škrtić, D., Mamljenje djeteta za zadovoljenje spolnih potreba uporabom informacijsko- komunikacijske tehnologije, Zbornik Pravnog fakulteta Sveučilišta u Rijeci, god. 34, br. 2, 2013., str. 1139.-1170.

6. Derenčinović, D., Dječja pornografija na Internetu - o kažnjivosti posjedovanja i virtualnoj dječjoj pornografiji, Hrvatski ljetopis za kazneno pravo i praksu, god. 10, br. 1, 2003, str. 3.-25.

7. Henshaw, M.; Ogloff1, J. R. P.; Clough, J. A., A Critical Review of the Literature on the Online Child Pornography Offender, Sex Abuse, 2015, pii: 1079063215603690, p. 15.

8. Kagle, J., Koples, S., Social work records, Prospect Heights, IL: Waveland, 2008.

9. Kahn, K., Child pornography on the Internet, Police Journal, 2000, pp. 7-17.

10. Klain, A. J., Davies, H. J., Hicks, M. A., Child Pornography: The Criminal-Justice-System Response, USA: American Bar Association Center on Children and National Center for Missing and Exploited Children, 2001, p. 1.

11. Luepker, E., Norton, L., Record keeping in psychotherapy and counseling: Protecting confidentiality and the professional relationship, New York: Brunner-Routledge. 2002, pp. 1-3.

12. McCarthy, J. A., Internet sexual activity: A comparison between contact and non-contact child pornography offenders, Journal of Sexual Aggression, vol. 16, no. 2, 2010, pp. 181-195.

13. Ogresta, J.; Rimac, I.; Ajduković, M.; Skokandić, L., Analiza obilježja prijavljenih događaja nasilja nad djecom u obitelji evidentiranih u centrima za socijalnu skrb, Ljetopis socijalnog rada, god. 19, br. 3, 2012., str. 439.-477.

14. Price, M.; Lambie, I.; Krynen, A. M., New Zealand adult internet child pornography offenders, Journal of Criminal Psychology, vol. 5, no. 4, 2015, pp. 262-278.

15. Reamer, F., Documentation in social work: Evolving ethical and risk-management standards, Social 
Work, no. 50, 2005, pp. 325-334.

16. Richards, K., Misperceptions about child sex offenders, Trends and issues in crime and criminal justice, no. 429, 2011, pp. 2-3.

17. Seto, M. C.; Cantor, J. M.; Blanchard, R. Child pornography offenses are a valid diagnostic indicator of pedophilia, Journal of Abnormal Psychology, vol. 115, no. 3, 2006, pp. 610-615.

18. Seto, M. C., Eke, A. W., The Criminal Histories and Later Offending of Child Pornography Offenders. Sexual Abuse, A Journal of Research and Treatment, vol. 17, no. 2, 2005, pp. 201-210.

19. Sidel, N. L., Social Work Documentation: A Guide to Strengthening Your Case Recording, Washington, D. C.: NASW Press, 2011.

20. Stanley, J., Child abuse and the Internet, Nartional Child Protection Clearinghouse, no. 15, 2001, pp. 1-19.

21. Škrtić, D., Mamljenje djeteta za zadovoljenje spolnih potreba uporabom informacijsko- komunikacijske tehnologije, Zbornik Pravnog fakulteta Sveučilišta u Rijeci, god. 34, br. 2, 2013., str. 1139.-1170.

22. Taylor, M.; Quayle, E.; Holland, G., Child Pornography: The Internet and Offending Isuma - Canadian, Journal of Policy Research, vol. 2, no. 2, 2001, pp. 94-100.

23. Vejmelka, L., Majdak, M., Specifičnosti nasilja kod djece smještene u domovima, Majdak, M.; Vejmelka, L.; Radat, K.; Vuga, A., (ur.), Zbornik konferencije Nasilje na Internetu među i nad djecom i mladima, Zagreb, 2014., str. 51.-74.

24. Wolak, J.; Finkelhor, D.; Mitchell, K. J., Child-Pornography Possessors Arrested in Internet-Related Crimes: Findings from the National Juvenile Online Victimization Study. California, Florida, New York, Texas: National Center for Missing and Exploited Children, 2005, pp. 9-10.

\section{POPIS PROPISA, AKATA I SUDSKIH ODLUKA}

1. Kazneni zakon, Narodne novine, broj 110/1997, 129/2000, 111/2003, 71/2006, 105/2004, 125/2011, 144/2012, 125/2011, 144/2012, 56/2015 i 61/2015 ispravak).

2. Zakon o potvrđivanju Fakultativnog protokola uz Konvenciju o pravima djeteta o prodaji djece, dječjoj prostituciji i dječjoj pornografiji, Narodne novine, Međunarodni ugovori, broj 5/2002.

3. Zakon o probaciji, Narodne novine, broj 143/2012.

4. Pravilnik o načinu obavljana probacijskih poslova, Narodne novine, broj 143/2012.

\section{MREŽNI IZVORI}

1. Državni zavod za statistiku, Punoljetni počinitelji kaznenih djela, prijave, optužbe i osude u 2014. Statistička izvješća: Zagreb, 2015. URL=http://www.dzs.hr/, pristupljeno_28. prosinca 2015.

2. Državni zavod za statistiku (2016). Primjena informacijskih i komunikacijskih tehnologija (IKT) u kućanstvima i kod pojedinaca u 2016. Prvi rezultati. Priopćenje, LIII (2.3.2.: Zagreb, 2016. URL=http://www.dzs.hr/, pristupljeno 5. veljače 2017.

3. Europol, 2016. URL=https://www.europol.europa.eu/, pristupljeno 25. studenog 2016.

4. Europski parlament, Vijeće Europe, Direktiva o borbi protiv seksualnog nasilja i eksploatacije djece $i$ dječje pornografije, br. 2011/92/EU, 2011. URL=http://eur-lex.europa.eu/LexUriServ/LexUriServ. 
do?uri=OJ:L:2011:335:0001:0014:EN:PDF, pristupljeno 12. ožujka 2016.

5. Hrabri telefon, Poliklinika za zaštitu djece grada Zagreba, Istraživanje o iskustvima i ponašanju djece na internetu i društvenoj mreži Facebook, 2013. URL= http://www.poliklinika-djeca.hr/aktualno/ rijec-ravnateljice/nase-istrazivanje-koliko-vremena-i-uz-koje-rizike-djeca-provode-na-internetu-i-facebooku, pristupljeno 2. studenog 2015.

6. Kos, J., Rogić-Hadžalić, D. Kaznena djela na štetu djece i maloljetnika 2001 - 2006. Studije i analize 106, 2009. URL=http://www.dzs.hr/Hrv/publication/studije/Studije-i-analize-106.pdf, pristupljeno 14. siječnja 2016.

7. MUP. Odjel za visokotehnološki kriminalitet. 2017. URL=http://www.policija.hr/159. aspx, pristupljeno 15.veljače 2017.

8. Seto, M., Chapter 4: Internet-Facilitated Sexual Offending, 2015. URL=http://www.smart.gov/SOMAPI/sec1/ch4-internet.html, pristupljeno 25. studenog 2016.

9. Taylor, M., Quayle, E., Holland, G., The COPINE project, 2001. URL=http://web.archive.org/ web/20071129132438/http://copine.ie/, pristupljeno 21. ožujka 2016.

10. Unicef, Konvencija o pravima djeteta, 1991. URL=http://unicef.hr, pristupljeno 17. listopada 2015.

11. Vijeće Europe, Konvencija o kibernetičkom kriminalu, 2001. URL=http://narodne-novine.nn.hr/clanci/medunarodni/2002-07-9-119.html, pristupljeno 17. listopada 2015.

12. Vijeće Europe, Konvencija o zaštiti djece od seksualnog iskorištavanja i seksualnog nasilja, 2007. UR$\mathrm{L}=\mathrm{http} / /$ www.coe.int/t/dghl/standardsetting/children/Source/Lanz arote Convention-hr1.pdf, pristupljeno 17. listopada 2015. 
Lucija Vejmelka*

Goran Brkic***

Katarina Radat ${ }^{* * *}$

\section{CHILD PORNOGRAPHY ON THE INTERNET - DETERMNINATS OF CONVICTED OFFENDERS}

\section{Summary}

Harmful activities by means of modern technology also include detrimental contacts when a child is targeted and chosen as a victim by another child or adult person. The paper deals with presentation of preliminary research results concerning the group of harmful contacts that pertain to the involvement in activities related to the Internet child pornography.

The research analyzed the probation service documentation of 76 cases of convicted perpetrators of child exploitation for purposes of the Internet pornography. The presentation of the results includes information on the perpetrators and type of offenses, in addition to other data which will contribute to better understanding of criminal offenses that harm children and juveniles through child pornography and electronic violence. The presentation of the results aims at objectives analysis but also contributes to the sparse field of research.

Keywords: $\quad$ Child pornography on the Internet, documentation analysis, adult convicted offenders

\section{(i) (8)}

This work is licensed under a Creative Commons

Attribution-NonCommercial 4.0 International License.

* Lucija Vejmelka, PhD, Assistant Professor, Department of Social work, Faculty of Law, University of Zagreb. Nazorova 51, 10000 Zagreb, Republic of Croatia. E-mail address: lucija.vejmelka@pravo.hr. ORCID: https://orcid.org/0000-0002-7531-8457.

** Goran Brkić, Graduated social worker, Ministry of Justice. Ul. Grada Vukovara 49, 10000 Zagreb, Republic of Croatia. E-mail address: goran.brkic@pravosudje.hr. ORCID: https://orcid.org/0000-0003-4753-8468.

*** Katarina Radat, Graduated social worker, Social support society, Bijenicka 97, 10000 Zagreb, Republic of Croatia. E-mail address: radat.katarina@gmail.com. ORCID: https://orcid.org/0000-0003-0580-9792. 